\title{
KARAKTERISASI ENZIM KITINASE DARI ISOLAT BAKTERI TERMOFILIK B1211 ASAL
} AIR PANAS BORA

\section{[Characterization of Chitinase from B1211 Thermophile Bacteria Isolates in Bora Hot Springs]}

\author{
Jaya Hardi ${ }^{1^{*}}$, Ruslan', Abd. Rahman Razak', Silva ${ }^{1}$ \\ 1 Jurusan Kimia Fakultas MIPA, Universitas Tadulako \\ J. Soekarno Hatta Km.9, Kampus Bumi Tadulako Tondo Palu, Telp. 0451- 422611
}

Diterima 19 Juni 2017, Disetujui 2 Agustus 2017

\begin{abstract}
The objective of this research was to characterize of chitinase from thermophile bacteria that was living in Bora hot spring. The B1211 isolates were used to production of crude chitinase on MSM broth media with chitin colloidal concentration of $1 \%$ and incubation temperature of $60^{\circ} \mathrm{C}$ for 3 days. The chitinase activity was analyzed based on $\mathrm{N}$-acetyl-D-glucosamine standard. The results showed that optimal temperature, optimal $\mathrm{pH}$, and substrate concentration of crude chitinase is $600 \mathrm{C}, 7$, and $2 \%$, respectively. The kinetic of chitinase has $V \max$ and $\mathrm{Km}$ value of $0.72 \mathrm{U} / \mathrm{ml}$ and $0.01 \mathrm{mg} / \mathrm{ml}$. The metal ions which were as activator are $\mathrm{Hg}^{2+}, \mathrm{Zn}^{2+}, \mathrm{Al}^{3+}$, and $\mathrm{Cu}^{2+}$ ion, whereas $\mathrm{Li}^{3+}, \mathrm{Ca}^{2+}$, and $\mathrm{K}^{+}$ions were contributed as inhibitor
\end{abstract}

Keywords : thermophile bacteria, B1211 isolates, chitinase, characterization

\begin{abstract}
ABSTRAK
Penelitian ini bertujuan untuk mengkarakterisasi enzim kitinase dari bakteri termofilik asal sumber air panas Bora. Isolat bakteri B1211 digunakan pada produksi enzim kitinase pada media MSM cair yang diperkaya dengan konsentrasi koloidal kitin $1 \%$ pada suhu inkubasi $60^{\circ} \mathrm{C}$ selama 3 hari. Aktivitas enzim kitinase dianalisis berdasarkan standar $\mathrm{N}$-asetil-D-glukosamin untuk kondisi suhu dan $\mathrm{pH}$ optimum, pengaruh substrat, dan pengaruh ion logam. Hasil penelitian menunjukkan enzim kitinase memiliki suhu optimum, $\mathrm{pH}$ optimum, dan konsentrasi substrat terbaik, masing-masing $60^{\circ} \mathrm{C}, \mathrm{pH} 7$, dan $2 \%$. Kinetika enzim kitinase memiliki Vmaks dan $\mathrm{Km}$, yaitu $0,72 \mathrm{U} / \mathrm{mL}$ dan $0,01 \mathrm{mg} / \mathrm{mL}$. lon logam $\mathrm{Hg}^{2+}, \mathrm{Zn}^{2+}, \mathrm{Al}^{3+}$, dan $\mathrm{Cu}^{2+}$ berfungsi sebagai activator, sedangkan ion $\mathrm{Li}^{3+}, \mathrm{Ca}^{2+}$, dan $\mathrm{K}^{+}$cenderung sebagai inhibitor terhadap enzim kitinase.
\end{abstract}

Kata kunci: bakteri termofilik, isolat B1211, kitinase, karakterisasi 


\section{LATAR BELAKANG}

Kitin merupakan biopolimer berupa homopolimer dari $\quad \beta-1,4-N$-asetil-Dglukosamin dengan kelimpahan terbanyak di alam setelah selulosa (Chen et al., 2010). Penelitian tentang kitin dan turunannya telah banyak dikembangkan, seperti oligomer kitin, N-asetil-Dglukosamin, dan kitosan, karena produkproduk tersebut banyak dimanfaatkan untuk keperluan biomedis, farmasi, dan pertanian (Purwani et al., 2002). Salah satu turunan kitin yang memiliki nilai jual tinggi adalah produk hasil hidrolisis senyawa kitin baik dalam bentuk oligomer maupun monomernya. Oligomer kitin berfungsi untuk meningkatkan sistem imunitas tubuh, bersifat antibakteri dan antijamur, juga dapat meningkatkan daya tahan tanaman. Sementara monomer kitin dalam bentuk $\mathrm{N}$ asetil-D-glukosamin dimanfaatkan sebagai suplemen, obat pengontrol kadar gula darah, dan memiliki efek antiinflamasi. Hasil hidrolisis kitin dalam bentuk monomer atau N-asetil-D-glukosamin dapat digmanfaatkan pada industri kosmetik dalam mengurangi hilangnya hiperpigmentasi (Herdyastuti et al., 2009).

Hidrolisis kitin dapat ditempuh dengan cara kimiawi ataupun enzimatik (Chen et al., 2010). Degradasi kitin secara enzimatis memiliki keunggulan dibandingkan secara kimiawi karena metode yang digunkanan sederhana, cepat dan proses pemotongan ikatan glikosidik yang lebih spesifik untuk menghasilkan senyawa-senyawa turunan kitin. Enzim yang umum digunakan dan spesifik pada hidrolisis kitin adalah enzim kitinase.

Kitinase (E.C. 3.2.1.14) dapat diperoleh dari beberapa jenis organisme, seperti crustacea, bakteri, jamur, dan serangga. Khusus pada penggunaan bakteri sebagai penghasil enzim kitinase dapat dilakukan deteksi awal berupa analis zona bening pada medium selektif agar dan dilanjutkan dengan perhitungan nilai Indeks Kitinolitik (IK) (Herdyastuti et al., 2009). Selain indeks kitinolitik, aktivitas kitinase menjadi parameter penting lainnya dalam pemilihan isolat bakteri termofil terbaik. Salah satu bakteri penghasil kitinase yang banyak mendapatkan perhatian adalah bakteri termofil, karena dapat menghasilkan enzim yang bersifat termostabil atau tahan pada suhu yang tinggi dan menghasilkan proses reaksi yang lebih cepat. Jenis bakteri termofil sebelumnya telah diisolasi dari sumur hidrotermal di Manado Sulawesi Utara dengan nilai IK 2,40 (Chasanah, 2004 dan Purwani et al., 2002). Natsir et al. (2009) melaporkan isolasi bakteri termofil (isolat ST-3) dilakukan pada $\mathrm{pH} 7$ dan suhu $60^{\circ} \mathrm{C}$ dengan aktivitas kitinase $0,225 \mathrm{U} / \mathrm{mL}$.

Enzim kitinase yang bersifat termostabil dapat diperoleh pada bakteri yang hidup di daerah dengan suhu tinggi, seperti sumur hidrotermal, kawah gunung berapi, dan lain sebagainya (Purwani et al., 2002). Indonesia yang kaya akan gunung berapi tentunya sejalan dengan melimpahnya sumber air panas, maka potensi pengembangan produksi kitinase 
dari isolasi bakteri termofil sangatlah besar. Salah satu dari beberapa potensi tersebut ialah air panas Bora yang terletak di Kabupaten Sigi Provinsi Sulawesi Tengah.

Bakteri termofilik dari sumber air panas Bora sebelumnya telah diisolasi untuk menghasilkan kitinase dengan aktivitas kitinolitik tertinggi pada isolat bakteri B1211 (Khoridah, 2015). Selanjutnya isolat bakteri B1211 tersebut juga telah dikembangkan oleh Hardi et al. (2016) untuk memproduksi kitinase kasar dan menunjukkan aktivitas kitinase yang tinggi $(0,75 \mathrm{U} / \mathrm{mL})$. Berdasarkan hal tersebut sangat potensial untuk mengembangkan atau melanjutkan kajian pada isolat bakteri B1211 tersebut ke arah karakterisasi enzim kitinase yang dapat dijadikan acuan untuk aplikasinya yang lebih luas.

\section{METODE PENELITIAN}

\section{Bahan dan Peralatan}

Bahan utama penelitian ini adalah isolat bakteri B1211, kitin, MSM cair dengan kolidal kitin (komposisi: 0,1\% $\mathrm{KH}_{2} \mathrm{PO}_{4} ; 0,7 \% \quad\left(\mathrm{NH}_{4}\right)_{2} \mathrm{SO}_{4} ; \quad 0.1 \% \quad \mathrm{NaCl} ;$ $0,01 \% \mathrm{MgSO}_{4} .7 \mathrm{H}_{2} \mathrm{O} ; 0.05 \%$ ekstrak ragi, dan $0.5 \%$ koloidal kitin), $\mathrm{NaCl}$ fisiologis $0.9 \%$, bufer fosfat, bufer sitrat, bufer borat, $\mathrm{HCl}$ pekat, $\mathrm{NaOH} 12 \mathrm{~N}$, glass wool, $\mathrm{NaCl}$, $\mathrm{HgCl}_{2}, \mathrm{CaCl}_{2}, \mathrm{MgCl}_{2}, \mathrm{ZnCl}_{2}, \mathrm{CuCl}_{2}, \mathrm{LiCl}_{2}$, $\mathrm{KCl}, \mathrm{FeCl}_{3}, \mathrm{AlCl}_{3}$, etanol 96\%, dan aquades. Bahan lainnya untuk analisis meliputi: pewarna Schales, dan N-asetil-Dglukosamin.

Alat yang digunakan meliputi spektrofotometer UV-Vis, thermoshaker,
$\mathrm{pH}$ meter, oven, inkubator, laminar air flow, sentrifugasi, penangas air, pipet mikro, vortex, botol sampel, dan alat-alat gelas yang umum digunakan di laboratorium kimia.

\section{Prosedur Penelitian}

\section{Produksi Ekstrak Kitinase}

Produksi ekstrak kitinase menggunakan metode Hardi et al. (2016). Kultur awal bakteri (starter) dibuat dari stok isolat bakteri B1211, disuspensikan pada $50 \mathrm{~mL}$ larutan fisiologis $0,9 \% \mathrm{NaCl}$. Produksi enzim kitinase diawali dengan sebanyak satu $\mathrm{mL}$ inokulum diambil dan dipindahkan pada media starter yaitu media MSM cair (tanpa koloidal kitin) dan diinkubasi pada suhu $37^{\circ} \mathrm{C}$ selama 24 jam. Langkah selanjutnya diambil sebanyak 1 $\mathrm{mL}$ dan dipindahkan pada media produksi (MSM cair diperkaya koloidal kitin 1\%), pada $\mathrm{pH} 7$ dan selanjutnya diinkubasi di dalam termoshake pada kecepatan $60 \mathrm{rpm}$ pada suhu $60^{\circ} \mathrm{C}$ selama 3 hari. Medium selanjutnya disentrifugasi dengan kecepatan 10.000 rpm selama 15 menit. Supernatan yang diperoleh adalah ekstak enzim kitinase kasar yang siap ditentukan aktivitasnya (Ueda \& Arai, 1992) dan karakteristiknya.

Karakterisasi Estrak Kitinase (Modifikasi metode Sarni dkk., 2015 dan Noviendri dkk., 2008)

\section{Penentuan $\mathrm{pH}$ optimum}

Aktivitas kitinase diuji pada beberapa variasi $\mathrm{pH}$. Penentuan $\mathrm{pH}$ optimum dilakukan dengan mereaksikan enzim dengan buffer pada $\mathrm{pH}$ yang berkisar 
antara 4-9. Buffer yang digunakan dalam penentuan $\mathrm{pH}$ optimum adalah $0,2 \mathrm{M}$ buffer sitrat $(\mathrm{pH} \mathrm{4,5}$, dan 6), buffer fosfat $(\mathrm{pH} 7$ dan 8), dan buffer borat ( $\mathrm{pH} 9)$.

\section{Penentuan suhu optimum}

Mengukur aktivitas kitinase pada suhu inkubasi yang beragam. Suhu optimum ditentukan dengan mereaksikan ekstrak kasar enzim dengan substrat pada suhu $30^{\circ} \mathrm{C}, 40^{\circ} \mathrm{C}, 50^{\circ} \mathrm{C}, 60^{\circ} \mathrm{C}$, dan $70^{\circ} \mathrm{C}$ yang dilakukan pada $\mathrm{pH}$ optimumnya.

\section{Penentuan pengaruh konsentrasi substrat}

Analisis aktivitas enzim dengan menggunkan konsentrasi substrat (koloidal kitin) yang divariasikan yakni dari $0,1 \% ; 0,2$ $\%$; 0,3\%; 0,4\%; 0,5\%; 0,6\%; 0,7\%; dan $0,8 \%$. Perlakuan ini menggunakan $\mathrm{pH}$ dan suhu optimum yang telah diperoleh sebelumnya dengan waktu inkubasi selama 30 menit. Selanjutnya ditentukan kinetika enzim kitinase.

\section{Penentuan pengaruh ion logam}

Pengujian dilakukan dengan mereaksikan enzim pada $\mathrm{pH}$, suhu dan konsentrasi substrat optimum. Pada saat reaksi, ion logam ditambahkan ke dalam tabung sampel dan kontrol. Beberapa ion logam yang digunakan merupakan kation bivalen dengan konsentrasi $10 \mathrm{mM}$ antara lain $\mathrm{Hg}^{2+}, \mathrm{Zn}^{2+}, \mathrm{Mg}^{2+}, \mathrm{Li}^{2+}, \mathrm{Cu}^{2+}, \mathrm{Ca}^{2+}, \mathrm{Na}^{+}$, $\mathrm{K}^{+}, \mathrm{Al}^{3+}$, dan $\mathrm{Fe}^{3+}$ dalam bentuk garam kloridanya. Pada saat bersamaan, dibuat kontrol positif yang tidak ditambahkan dengan ion logam. Hasil reaksi selanjutnya ditentukan nilai aktivitas enzimnya.

\section{HASIL DAN PEMBAHASAN \\ Karakteristik Ekstrak Kitinase}

\section{1. pH Optimum}

Tingkat keasaman lingkungan akan mempengaruhi kecepatan kerja enzim dalam mengkatalisis suatu reaksi, karena konsentrasi ion $\mathrm{H}^{+}$dapat mempengaruhi struktur tiga dimensi enzim dan aktivitasnya. $\mathrm{pH}$ optimum enzim merupakan kondisi dimana struktur tiga dimensi enzim sangat efektif dalam berinteraksi dengan susbstrat sehingga reaksi mencapai optimal (Lehninger, 1982 dan Purkan et al., 2014).

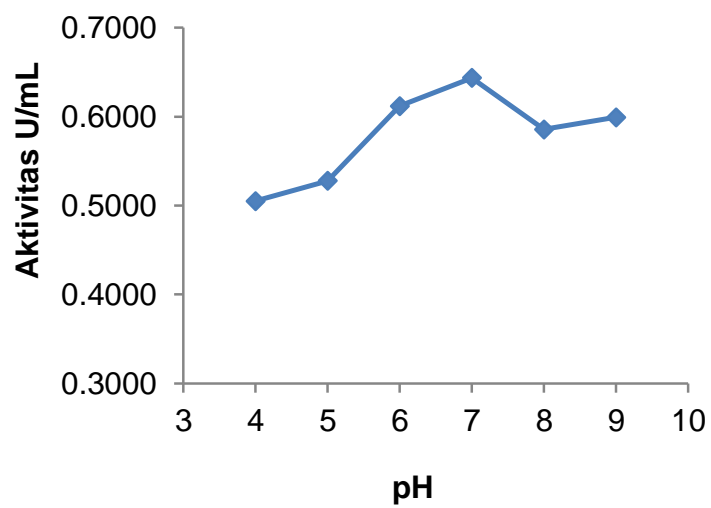

Gambar 1 Hubungan antara aktivitas kitinase terhadap $\mathrm{pH}$

Kitinase dari isolat B1211 memiliki kondisi optimum pada $\mathrm{pH} 7$ dengan aktivitas 0,64 U/mL (Gambar 1). Hal ini sesuai dengan $\mathrm{pH}$ lingkungan normalnya. Pada penelitian sebelumnya, ekstrak kitinase dari isolat bakteri ST-3,2b juga memiliki $\mathrm{pH}$ optimum pada $\mathrm{pH} 7$ dengan aktivitas 0,26 U/mL (Natsir et al., 2009). Nilai pH optimum 7 juga ditemukan pada enzim kitinase dari isolate bakteri termofil 13,5 asal Manado (Jayanti, 2002), isolat K29-14 yang diisolasi dari kawah kamojang jawa barat (Rahayu et al., 2004) dan isolat 
bakteri termofilik GP18 yang diisolasi dari sumber air panas Gunung Pancar (Lestari, 2000).

\section{Suhu Optimum}

Temperatur atau suhu dapat meningkatkan aktivitas enzim sebanyak dua kali lipat hingga pada kondisi optimum setiap kenaikan $10^{\circ} \mathrm{C}$ di atas suhu minimumnya (Lehninger, 1982).

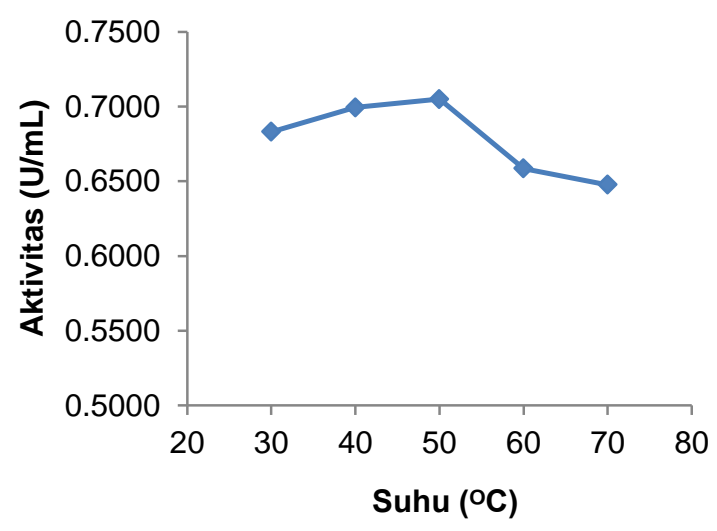

Gambar 2 Hubungan antara aktivitas kitinase terhadap suhu

Gambar 2 menunjukkan bahwa aktivitas ekstrak enzim kitinase isolat B1211 meningkat mulai suhu $30^{\circ} \mathrm{C}$ hingga $50^{\circ} \mathrm{C}$ dengan aktivitas tertinggi $0,71 \mathrm{U} / \mathrm{mL}$ dan selanjutnya pada suhu $60^{\circ} \mathrm{C}$ terjadi penurunan aktivitas ekstrak enzim kitinase. Pada penelitian Natsir et al. (2009), isolat bakteri ST-3,2b meningkat mulai suhu $37^{\circ} \mathrm{C}$ sampai $60^{\circ} \mathrm{C}$ tetapi mengalami penurunan aktivitas pada suhu $65^{\circ} \mathrm{C}$ dengan aktivitas kitinase tertinggi $0,10 \mathrm{U} / \mathrm{mL}$. Aktivitas enzim akan meningkat seiring meningkatnya suhu sampai tingkat optimal, kenaikan suhu akan meningkatkan energi kinetik sehingga tumbukan antar molekul akan semakin cepat, sehingga semakin mudah terbentuk kompleks enzim-substrat dan produk yang terbentuk juga semakin banyak (Natsir et al., 2009). Akan tetapi, pada suhu yang lebih tinggi akan menyebabkan aktivitas enzim menurun karena terjadi denaturasi atau kerusakan struktur enzim (Pratiwi et al,, 2015).

\section{Pengaruh Konsentrasi Substrat}

Konsentrasi substrat maksimum isolat bakteri termofil B1211 dihasilkan pada konsentrasi $0,2 \%$ dengan aktivitas 0,71 $\mathrm{U} / \mathrm{mL}$ (Gambar 3). Pada penelitian Natsir et al., (2009), konsentrasi substrat maksimum dari isolat bakteri ST-3,2b dihasilkan pada konsentrasi $0,3 \%$ dengan aktivitas 0,05 $\mathrm{U} / \mathrm{mL}$. Pada penelitian ini aktivitas kitinase yang dihasilkan lebih tinggi bila dibandingkan dengan aktivitas kitinase pada penelitian Natsir et al. (2009).

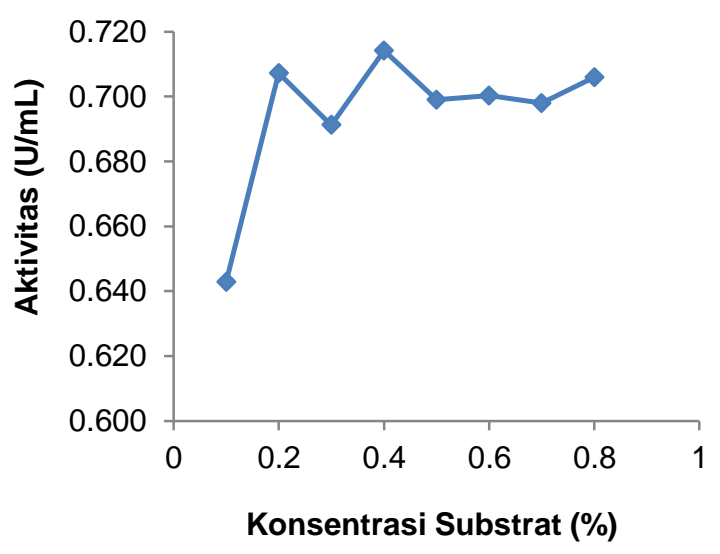

Gambar 3 Hubungan antara aktivitas ekstrak kitinase dengan konsentrasi substrat

Pada konsentrasi rendah, substrat hanya sedikit terikat pada bagian aktif enzim, sedangkan jika konsentrasi diperbesar, maka semakin banyak substrat yang berinteraksi dengan sisi aktif enzim. Akan tetapi, apabila konsentrasi substrat berlebih, maka kecepatan reaksi katalisispun menjadi konstan (Poedjiadi dan Supriyanti, 2006). 


\section{Pengaruh Ion Logam}

Salah satu zat yang dapat berfungsi sebagai aktivator atau inhibitor dalam proses katalisis enzim adalah ion logam. Palmer (1991) yang diacu dalam Sarni et al. (2015) mengemukakan bahwa ion logam pada konsentrasi tertentu dapat berfungsi mengaktifkan enzim (aktivator) dan juga dapat menghambat kerja enzim (inhibitor).

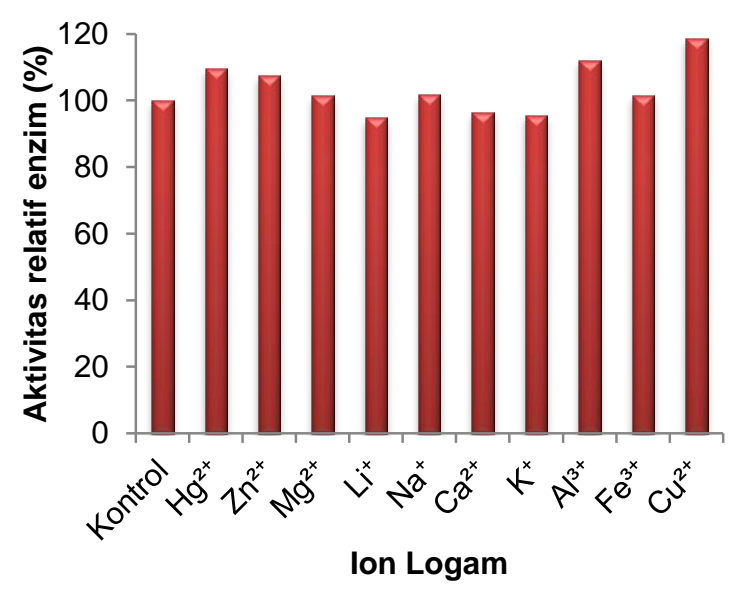

Gambar 4 Pengaruh ion logam terhadap aktivitas kitinase

Hasil penelitian menunjukkan bahwa ion logam $\mathrm{Hg}^{2+}, \mathrm{Zn}^{2+}, \mathrm{Na}^{+}, \mathrm{Al}^{3+}$, dan $\mathrm{Cu}^{2+}$ meningkatkan aktivitas enzim kitinase (aktivator) dengan aktivitas tertinggi pada penggunaan logam $\mathrm{Cu}^{2+}$ yang meningkatkan aktivtias kitinase 19\%. Sementra ion logam $\mathrm{Li}^{+}, \mathrm{K}^{+}$, dan $\mathrm{Ca}^{2+}$ cenderung menurunkan aktivitas enzim atau bertindak sebagai inhibitor dengan penurunan tertinggi ( $>5 \%$ ) terjadi pada ion Litium (Gambar 4). Noviendri et al. (2008) melaporkanbahwa kation $\mathrm{Mn}^{2+}, \mathrm{Mg}^{2+}, \mathrm{Cu}^{2+}$, $\mathrm{Co}^{2+}, \mathrm{Zn}^{2+}, \mathrm{Ba}^{2+}, \mathrm{NH}^{4+}, \mathrm{K}^{+}$, dan $\mathrm{Na}^{+}$ bertindak sebagai inhibitor terhadap kitinase isolat $\mathrm{T} 5 \mathrm{a} 1$, sedangkan kation $\mathrm{Fe}^{3+}$ dan $\mathrm{Ca}^{2+}$ berfungsi sebagai aktivator.

\section{Kinetika Ekstrak Kitinase}

Laju maksimum reaksi enzimatik dapat ditentukan dengan meningkatkan konsentrasi substrat hingga laju pembentukan produk menjadi konstan. Pada kondisi laju yang maksimum ( $\left.\mathrm{V}_{\text {maks }}\right)$, sisi aktif enzim akan berikatan secara menyeluruh dengan substrat sehingga kompleks enzim substrat (ES) berjumlah sama dengan jumlah total enzim (Lehninger, 1982).

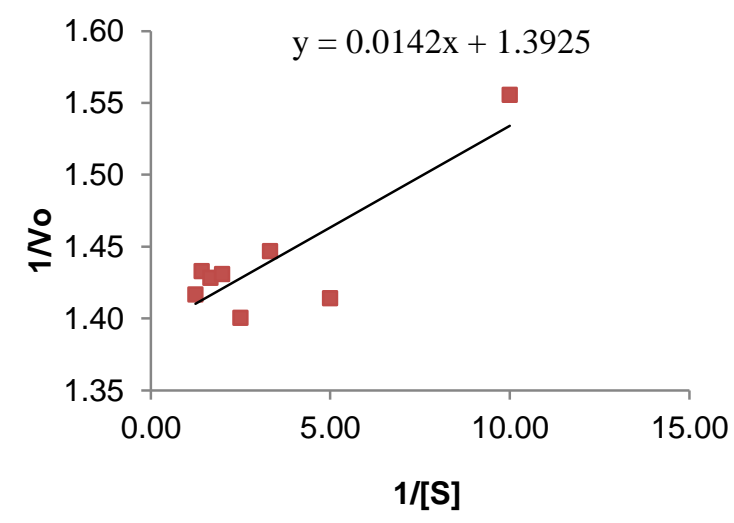

Gambar 5 Grafik Lineweaver - Burk, hubungan antara konsentrasi substrat (S) dengan laju reaksi (Vo)

Kurva di atas gambarkan pembentukan produk pada saat awal oleh suatu enzim pada kadar substrat yang bervariasi (S). Berdasarkan Gambar 5 dapat diperoleh nilai $V_{\text {maks }}$ dan $K_{m}$ ekstrak enzim kitinase dari isolat bakteri B1211 adalah $0,72 \mathrm{U} / \mathrm{mL}$ dan $0,01 \mathrm{mg} / \mathrm{mL}$. Bila dibandingkan dengan enzim kitinase dari isolat bakteri T5a1 asal terasi dengan nilai $\mathrm{V}_{\text {maks }}$ dan $\mathrm{K}_{\mathrm{m}}$ yaitu $0,005 \mathrm{U} / \mathrm{mL}$ dan 1,04 $\mathrm{U} / \mathrm{mL}$ (Noviendri et al., 2008). Hasil yang diperoleh pada penelitian ini berbeda dengan hasil penelitian tersebut dikarenakan bakteri yang digunakan berbeda yaitu isolat bakteri T5a1 asal 
terasi. Penelitian Chasanah et al. (2009) juga menghasilkan nilai $\mathrm{V}_{\text {maks }}$ dan $\mathrm{K}_{\mathrm{m}}$ enzim kitosanase bakteri asal lingkungan laut yaitu $1,25 \mathrm{U} / \mathrm{mL}$ dan $0,33 \mathrm{mg} / \mathrm{mL}$.

\section{KESIMPULAN}

Kitinase dari isolate B1211 memiliki pH dan suhu optimum, masing-masing 7 dan $50^{\circ} \mathrm{C}$. Konsentrasi substrat maksimum didapatkan pada koloidal kitin $0,2 \%$ dengan nilai $V_{\max }$ dan $\mathrm{K}_{\mathrm{m}}$, masing-masing 0,72 $\mathrm{U} / \mathrm{mL}$ dan $0,01 \mathrm{mg} / \mathrm{mL}$. Ion logam $\mathrm{Hg}^{2+}$, $\mathrm{Zn}^{2+}, \mathrm{Na}^{+}, \mathrm{Al}^{3+}$, dan $\mathrm{Cu}^{2+}$ bertindak sebagai aktivator, sedangkan ion logam $\mathrm{Li}^{+}, \mathrm{K}^{+}$, dan $\mathrm{Ca}^{2+}$ bertindak sebagai inhibitor.

\section{UCAPAN TERIMAKASIH}

Ucapan terimakasih penulis haturkan kepada pihak DRPM Kemenristek Dikti yang telah memberikan hibah penelitian.

\section{DAFTAR PUSTAKA}

Chasanah E. 2004. Chitosanase of Bacillus luchenformis MB-2 Isolatd form Manado Hot Spring Water. Disertasi. Bogor: Program Pascasarjana Institut Pertanian Bogor.

Chasanah, E., Zilda, D.S., Uria, A.R. 2009. Screening dan Characterization of Bacterial Chitosanase from Marine Environment. Journal of Coastal developmen. 12 (2) : 64-72.

Chen JK, Shen CR, Liu CL. 2010. NAcetylglucosamine: Production and Applications (Review). Marine Drugs. 8: 2493-2516.

Hardi, J., Jusman, J., Razak, A. R., \& Silva, S. (2016). Produksi dan Uji Aktivitas Enzim Kitinase Dari Isolat Bakteri Termofilik B1211 Asal Air Panas Bora. KOVALEN, 2(3)
Herdyastuti N, Raharjo TJ, Mudasir, Matsjeh S. 2009. Chitinase and Chitinolytic Microorganism: Isolation, Characterization and Potential. Indonesian Journal Chemistry. 9(1): 37-47.

Jayanti, J. F.L. 2002. Studi Kitinase dan Kitin Deasetilase Termostabil dari Isolat Asal Manado. Skripsi. Bogor: Jurusan Teknologi Pangan dan Gizi Fakultas Teknologi Pertanian IPB.

Khoridah EN. 2015. Produksi Enzim Kitosanase dari Isolat Bakteri Termofil Sumber Air Panas Bora. Skripsi. Palu: Jurusan Kimia FMIPA Universitas Tadulako.

Lehninger AL. 1982. Dasar-Dasar Biokimia, jilid 1, (diterjemahkan oleh: Maggy Thenawijaya). Jakarta: Erlangga.

Lestari P. 2000. Eksplorasi Enzim Termostabil dari Mikroba Termofil. J.Hayati. 17:21-25

Natsir H, Dali S, Astin, Trisanova. 2009. Isolasi dan Karakterisasi Enzim Kitinase dari Bakteri Termofil Isolat ST-3,2b. Jurnal IImiah Biologi Makassar. 4(1): 51-58.

Noviendri D, Fawzya YN, Chasanah E. 2008. Karakterisasi dan Sifat Kinetika Enzim Kitinase dari Isolat Bakteri T5a1 Asal Terasi. Jurnal Pascapanen dan Bioteknologi Kelautan dan Perikanan. 3(2): 123 - 129.

Pratiwi RS, Susanto TE, Wardani YAK, Sutrisno A. 2015. Enzim Kitinase Dan Aplikasi di Bidang Industri: Kajian Pustaka. Jurnal Pangan dan Agroindustri. 3 (3): 878-887.

Poedjiadi A., Supriyanti T. 2006. DasarDasar Biokimia Edisi Revisi. Jakarta: UI-Press.

Purkan, Azizah B, Baktir A, Sumarsih S. 2014. Eksplorasi Bakteri Kitinolitik dari Sampah Organik: Isolasi dan 
Karakterisasi Enzim Kitinase. J. Molekul. 9 : 128-135.

Purwani EY.,Toharisman A, Chasanah E, Laksmi JF, Welan V, Suhartono, Purwadaria T, Hwang JK, Pyun YR. 2002. Studi Pendahuluan Enzim Kitinase Extraseluler yang Dihasilkan Oleh Isolat Bakteri Asal Manado. Jurnal Teknologi dan Industri Pangan. 8(2): 111-117.

Rahayu, S., Tanuwidjaya, F., Rukayadi, Y., Suwanto, A., Suhartono, M.T., Hwang, J.K., Pyun, Y.R. 2004. Study of Thermostable Chitinase Enzymes from Indonesian Bacillus K29-14. J. Microbiol. Biotechnol. 14(4): 647-652.

Sarni, Natsir H, Dali S. 2015. Produksi dan Karakterisasi Enzim Kitosanase Dari Isolat Bakteri Klebsiella sp. Jurnal Techno. 4(2): 8 - 15.

Ueda M, Arai M. 1992. Purification and Some Properties of Chitinases from Aeromonas sp. No. 10S-24. Biosci. Biotech and Biochem. 56(3): 460464. 